\title{
News from the Academy
}

\author{
John Barnett
}

Published online: 10 July 2010

(C) Springer-Verlag 2010

\section{Professor Dr Gerd Wegener}

Fellow Wegener will retire this year, and on October 6, 2010, he will be officially honoured at the 15th Munich Wood Colloquium/"Münchener Holzkolloquium" of the Society of Friends and Sponsors of the "Holzforschung München" at the main lecture hall "Audimax", Munich Technical University (TUM).

His contributions to wood science have been recognised by the awards of the Federal Cross of Merit of Germany and the Schweighofer Prize (see volume 43 7/8 of this journal). As a longstanding editor of Wood Science and Technology he has acted as a vital link between the Academy and its Journal.

The Academy would like to take the opportunity offered in this issue of the journal, dedicated to Fellow Wegener, to thank him heartily for his work and wish him a long and happy retirement.

New Academy board members

The Academy congratulates the four Fellows who have been elected to the Academy Board to replace Fellows Allison, Faix, Meshitsuka and Ruel who retire after their six-year term of office in June 2010. The thanks of the Academy go to the retiring Fellows.

The new Board members are as follows:

Holger Militz, Institute of Wood Biology and Wood Technology, Georg-AugustUniversität Göttingen, Germany.

Christian Sales, CIRAD-FORET, Montpellier, France.

Peter Vinden, School of Forest and Ecosystem Science, The University of Melbourne, Australia.

Ulla Westermark, Luleå Tekniska Universitet, Luleå, Sweden These Fellows will serve on the Board until 2016. 
Newly elected fellows 2010

\section{Anatoly Chubinsky}

Head of the Department of Sawmilling and Wood Drying, St. Petersburg State Forest Technical Academy (SPbFTA), Russia

\section{Pedro Fardim}

Head of the Laboratory of Fibre and Cellulose Technology, Åbo Akademi, Åbo, Finland

\section{Guanben Du}

Vice President/, Southwest Forestry University (SWFU), Kunming, P. R. China Callum Hill

Professor in Materials Science, Centre for Timber Engineering, Edinburgh University, Scotland

\section{Yuji Imamura}

Research Institute for Sustainable Humanosphere, Kyoto University, Japan

\section{Takao Itoh}

Professor Emeritus, Kyoto University, Japan

\section{Tetsuo Kondo}

Kyushu University, Japan

\section{Gilles Pilate}

Head of the Breeding, Genetic and Physiology Research Unit, Unité de Recherches Amélioration Génétique et Physiologie Forestières (AGPF), INRAOrléans Research Centre, France

\section{Laurie Schimleck}

D. B. Warnell School of Forestry and Natural Resources (WSFNR), University of Georgia (UGA), Athens, USA

\section{Francis W.M.R. Schwarze}

Albert-Ludwigs-Universität, Freiburg im Br., Germany

\section{Shigehiko Suzuki}

Department of Forest Resources Science, Shizuoka University, Japan

\section{Kelin Ye}

Director, Research Institute of Wood Industry, Chinese Academy of Forestry, China

\section{Dingguo Zhou}

Director, Fast-growing Trees \& Agri-fibre Materials Engineering Centre of Jiangsu Province in China

John Barnett

Past President of IAWS 